\title{
In vitro estrogenic potency of phytoestrogen-glycosides and some plant flavanoids
}

\author{
J. C. Kalita ${ }^{1}$ and S. R. Milligan ${ }^{2}$ \\ ${ }^{1}$ Animal Physiology \& Biochemistry Laboratory, Dept. of Zoology, Gauhati University, Guwahati-781014, Assam, India \\ ${ }^{2}$ Biomedical Sciences Division, King's College London, University of London, UK \\ jogenck@yahoo.co.in
}

\begin{abstract}
Many plants produce chemicals that mimic or interact with hormonal signals in animals. Their presence in human diet is the object of many studies concerned with prevention of breast and prostate cancer, osteoporosis and other hormone-dependent diseases. Isoflavones, daidzein and genistein occurring either free or bound in glycosides are the main phytoestrogens in soya. The present study investigated the estrogenic activities of two isoflavones, two glucosylated isoflavones, one isoflavandiol, two flavanoids and some other plant-derived phenolic compounds. The bioassay used in this study was an estrogen responsive cell line Ishikawa Var-1. Besides, this study also used the recombinant yeast cells bearing the human estrogen receptor for confirming the actual estrogenic nature of the plant chemicals. There was a marked stimulation of alkaline phosphatase activity in Ishikawa cells and $\beta$-galactosidase activity in yeast cells by glucosylated isoflavones, genistin and daidzin. Considering the potency of body's endogenous estrogen (17 $\beta$-estradiol) as 100 , in the Ishikawa assay the relative estrogenic potency of these compounds were found to be genistein $(0.11)$, genistin $(0.06)$, daidzein $(0.08)$ and daidzin $(0.07)$. In the yeast cell assay, the relative estrogenic potencies were genistein (0.1), genistin (0.01), daidzein (0.02) and daidzin (0.002). Estrogenic potency of equol was almost equal $(0.18 \& 0.16)$ in both Ishikawa and yeast cell assays, respectively. While kaempferol and resveratrol were weakly estrogenic, quercetin, rutin, catechin, hesperetin and luteolin did not show any estrogenic activity.
\end{abstract}

Keywords: Phytoestrogen, flavanoids, estrogenic activity, glycosides.

\section{Introduction}

Phytoestrogens are diverse group of naturally occurring phenolic, non-steroidal compounds that are natural components of certain plant foods and fungi. Phytoestrogens have the ability to cause estrogenic and/or antiestrogenic effects because of their structural similarity to mammalian estrogen (17ß-estradiol). They can interact with the estrogen receptors alpha and/or beta and trigger the mechanisms of estrogenic action (Davis et al., 1999). Their influence on human health (beneficial or potential endocrine disruptors) and their usefulness as a natural alternative to hormonal replacement therapy is still debatable (Anderson et al., 1999; Ramsey et al., 1999; Russell et al., 2002). The class of phytoestrogens that captured much scientific attention is the isoflavones, namely genistein and daidzein. These diphenolic substances are predominantly found in the family Fabaceae (Leguminosae) with highest concentrations in soy beans. There are various in vivo methods to measure the estrogenic activity of phytoestrogens, including uterotropic assay (Benson et al., 1961), vaginal cornification assay in ovariectomized rats (Malaivijitnond et al., 2006; Cherdshewasart et al., 2008) and uterine vascular permeability method (Arvidson, 1977; Milligan et al., 1998). Early studies on the characterization of the estrogenic activity of the phytoestrogens involved in in vivo tests on rodents (Cheng et al., 1954; Bickoff et al., 1962; Whitten et al., 1992). The recently developed different in vitro cell culture-based bioassays for determination of estrogenic activity provide a simple alternative to the cumbersome and complex in vivo bioassays. But, many cellular models often express other endogenous receptors such as progesterone receptor and glucocorticoid receptor, which could interfere with the accurate determination of the estrogenic effects of plant extracts (Harmsen et al., 2007; Bitter, 2007).

Daidzin is the 7-O-glucoside of daidzein and is an isoflavone. Daidzin has been found in many plants like Kudzu (Pueraria lobata, Fabaceae) and in soybean (Osman \& Fett, 1983). It is found to be a cancer preventive and an antidipsotropic in animal models (Keung \& Vallee, 1998; Rezvani, 2003). Genistin is an isoflavone and was first isolated in 1931. Subsequently it was found that hydrolysis with hydrochloric acid produced genistein and glucose (Walter, 1941) and was found that this chemical possesses many biological activities. Flavonoids are widely distributed in many plants and herbs and are having varied biological activities. Flavonoids are the most important plant pigments for flower colouration producing yellow or red/blue pigmentation in petals designed to attract pollinator animals. They protect plants from attacks by microbes, fungi and insects (Galeotti et al., 2008). Flavonoids (specifically catechins) are the most common group of polyphenolic compounds in the human diet and are found ubiquitously in plants (Spencer \& Jeremy, 2008). Flavonols, the original bioflavonoids such as quercetin are also found ubiquitously but in lesser quantities. Both sets of compounds have evidence of health-modulating effects in animals. Results from experimental evidence suggest that flavonoids may modify allergens, viruses and carcinogens indicating the potentiality of biological
Research article

CIndian Society for Education and Environment (iSee)
"Phytoestrogen"

http://www.indjst.org
J.C.Kalita \& S.R.Milligan Indian J.Sci.Technol. 
"response modifiers". In vitro studies of flavonoids have displayed anti-allergic, anti-inflammatory (Yamamoto \& Gaynor, 2001), anti-microbial (Cushnie \& Lamb, 2005) and anti-cancer activities (De Sousa, 2007). Various attempts have been made to elucidate the exact molecular mechanism of many established phytoestrogens and other plant-derived phenolic compounds. As a result, various in vitro assays for estrogens have been developed. Recently Boonchird et al. (2010) studied the variations in the estrogenic activity of the phytoestrogen-rich plant, Pueraria mirifica, determined with yeast estrogen screen (YES) consisting of human estrogen receptors ( $h E R$ ) hER $\alpha$ and $h E R \beta$ and human transcriptional intermediary factor 2 (hTIF2) or human steroid receptor co-activator 1 (hSRC1), respectively, together with the $\beta$-galactosidase expression cassette.

There have been many studies to elucidate the estrogenic and other hormonal activities of phytoestrogens but very few information are available regarding the estrogenic nature of phytoestrogens glycosides, many plant flavanoids and other plant-derived phenolic compounds. The present study investigated the estrogenic activities of two isoflavones, two glucosylated isoflavones, one isoflavandiol and two flavanoids and some other plant-derived phenolic chemicals using two different estrogen-sensitive in vitro cell culture bioassays. The first bioassay used the estrogen responsive cell line Ishikawa Var-1. This bioassay was based on the stimulation of alkaline phosphatase enzyme activity as a measure of estrogen receptor activation in Ishikawa cells in the presence of any estrogenic substances in culture. The Ishikawa estrogen bioassay was used earlier extensively by different workers to determine the estrogenic activities of many plant chemicals (Littlefield et al., 1990; Markiewicz et al., 1993; Kalita, 1998; Kalita, 2006). The second bioassay used in this study was based on the stimulation of the transcriptional activity of the human estrogen receptor (hER) in recombinant yeast cells. The yeast screen has been previously used by many workers to characterize the estrogenic activity of various environmental chemicals by measuring the induction of estrogen-sensitive $\beta$-galactosidase activity (Routledge \& Sumpter, 1996, Milligan et al., 1998). Besides Ishikawa cells, the present study used the recombinant yeast cells bearing the human estrogen receptor for confirming the actual estrogen receptor interaction and nature of the plant chemicals tested.

\section{Materials and methods}

Chemicals: 17ß-estradiol (E2), genistein, genistin, daidzein, daidzin and other plant chemicals including the flavanoids were obtained from Acros Organics (Springfield, NJ) and Extrasynthese (Genay, France). All other chemicals and glassware used in the study were obtained from Sigma Chemical Company Ltd, Poole, Dorset, UK.
Vol. 3 No. 12 (Dec 2010)

ISSN: 0974- 6846
Preparation of $17 \beta$-estradiol standards and test compounds: Estradiol standard was prepared (3.68 mM) by adding $10 \mathrm{mg}$ of $E_{2}$ in $10 \mathrm{ml}$ of analytical grade ethanol in a sterile $20 \mathrm{ml}$ glass tube and all standards were prepared in alcohol from this stock. Test compounds were dissolved in $100 \%$ ethanol and diluted as per the experimental requirements.

Cell culture bioassays: Human Ishikawa cells and recombinant yeast cells were routinely cultured for all in vitro studies. All procedures were carried out using aseptic technique in a class II (Biohazards) laminar flow cabinet (Gelaire, UK). Human cells were treated as hazardous and additional safety procedures and decontamination procedures were carried out.

Determination of estrogenic activity: Pure chemicals were initially dissolved in ethanol and a range of concentration was prepared as required. Twenty $\mu \mathrm{l}$ aliquots were added to individual wells in a 96 well plate and the ethanol was evaporated. Estrogenic activity was determined in vitro using a human endometrial cell line, Ishikawa Var 1 (a gift from Dr. E. Gurpide, Mount Siani School of Medicine, New York). Cells $\left(2.5 \times 10^{4}\right.$ cells/well in $\left.100 \mu \mathrm{l}\right)$ were plated in 96-well plates in estrogen-free basal medium (1:1 mixture of phenol red free Ham's F 12 \& Dulbecco's modified Eagles medium \& 5\% charcoal stripped fetal bovine serum). Alkaline phosphatase activity was determined after $72 \mathrm{~h}$ by monitoring the hydrolysis of $p$-nitrophenyl phosphate to $p$-nitrophenol at $405 \mathrm{~nm}$ (Markiewicz et al., 1993). Estrogenic activity was confirmed using an estrogen-inducible yeast screen (Saccharomyces cerevisiae) expressing the human estrogen receptor and containing expression plasmids carrying estrogen-responsive sequences controlling the reporter gene lac- $Z$ (encoding the enzyme $\beta$-galactosidase) (it was a gift from Prof. J. Sumpter, Brunel University, UK). Estrogenic activity was determined from the metabolism of chlorophenol red $\beta$-Dgalactopyranoside by monitoring the absorbance at 540 nm (Routledge \& Sumpter, 1996).

Estrogenic activities of isoflavones and glucosylated isoflavones

Genistin and daidzin, the glycosides of genistein and daidzein respectively, were tested for their estrogenic activities using the Ishikawa and yeast cell assays. A range of concentrations $(0.1 \mathrm{nM}-1000 \mu \mathrm{M})$ of genistein, genistin, daidzein and daidzin was prepared in ethanol for assays. The assays were repeated 5 times.

Estrogenic activity of plant flavonoids and related plantderived phenolic compounds

A range of concentrations $(1 \mathrm{nM}-10,000 \mu \mathrm{M})$ of a number of the plant flavonoids like equol (isoflavandiol), apigenin, luteolin (flavone), kaempferol, resveratrol (stilbenoid), phloridzin, quercetin, rutin (flavonol), catechin (flavanol) and hesperetin, naringenin (flavanone) were prepared in ethanol before use in the assays. The estrogenic activity was determined using the Ishikawa
Research article

CIndian Society for Education and Environment (iSee)
"Phytoestrogen"

http://www.indjst.org
J.C.Kalita \& S.R.Milligan Indian J.Sci.Technol. 
and yeast cell assays. The assays were repeated for several occasions.

Statistical analysis: Statistical analysis was made using students't-test and Anova.

Fig. 1. Dose response stimulation of alkaline phosphatase activity in Ishikawa cells (a) \& $\beta$-galactosidase activity in yeast cells (b) by $17 \beta$-estradiol \& phytoestrogen \& their glycosides.

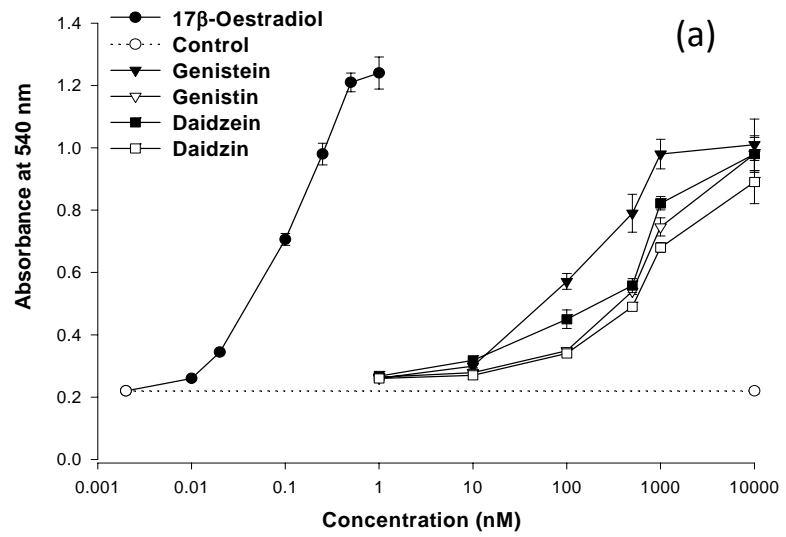

(b)

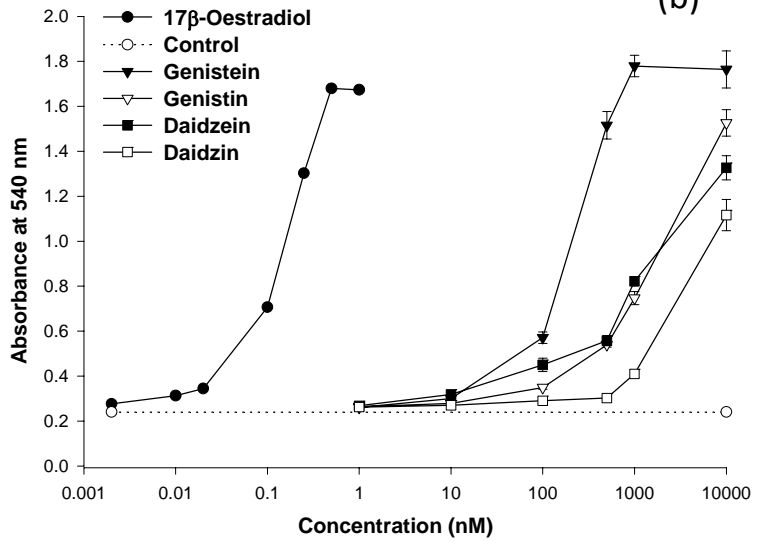

Data are expressed as mean \pm SEM ( $n=10$ wells per point), Where no error bars are visible, the errors were smaller than the symbols.

\section{Results}

Estrogenic activities of isoflavones and glucosylated isoflavones

To determine the estrogenic activities of isoflavones, genistein and daidzein, and their glucosylated derivatives (genistin and daidzin), these were tested for their estrogen receptor activation on both Ishikawa and yeast cell assays. There was a marked stimulation of alkaline phosphatase activity in Ishikawa cells (Fig. 1a) and $\beta$ galactosidase activity in yeast cells (Fig. 1b) by genistin and daidzin, the two glycosides of genistein and daidzein respectively. But their response was weaker than their aglycone forms.

Estrogenic activity of plant flavonoids and some plantderived phenolic compounds

Of the plant chemicals tested for their estrogenic activities only equol, apigenin and naringenin showed any marked stimulation of alkaline phosphatase activity in the Ishikawa cells (Fig. 2a) and $\beta$-galactosidase activity in the yeast cells (Fig. 2b) respectively. Kaempferol and resveratrol were weakly estrogenic in the both Ishikawa and yeast cell assays (Fig. 3a and Fig. 3b). Quercetin, rutin, catechin, hesperetin, and luteolin did not show any marked estrogenic activity in the both assays.

Table 1 and 2 show the $\mathrm{EC}_{50}$ values and relative estrogenic potencies of a number of plant chemicals as was estimated using estrogenic responses in the Ishikawa and yeast cell assays respectively. Considering the estrogenic potency of endogenous estrogen (17 $\beta$ estradiol) as $100 \%$, the potencies of the other chemicals tested was expressed as $\mathrm{EC}_{50}\left(\mathrm{E}_{2}\right) / \mathrm{EC}_{50}$ (compound) $\mathrm{x}$ 100. It was found that comparatively isoflavone, genistein has higher binding affinity to ER but exhibited estrogenic potency about 1000 times less potent than endogenous estrogen. Daidzein was found to be less potent than genistein in both the assays. Genistin and daidzin (the glycosides of genistein \& daidzein respectively) showed up their estrogenic responses in both the bioassays but their estrogenic potency was found to be less than their

Fig. 2. Dose response stimulation of alkaline phosphatase activity in Ishikawa cells (a); $\beta$-galactosidase activity in yeast cells (b) by $17 \beta$-estradiol, equol, apigenin \& naringenin.
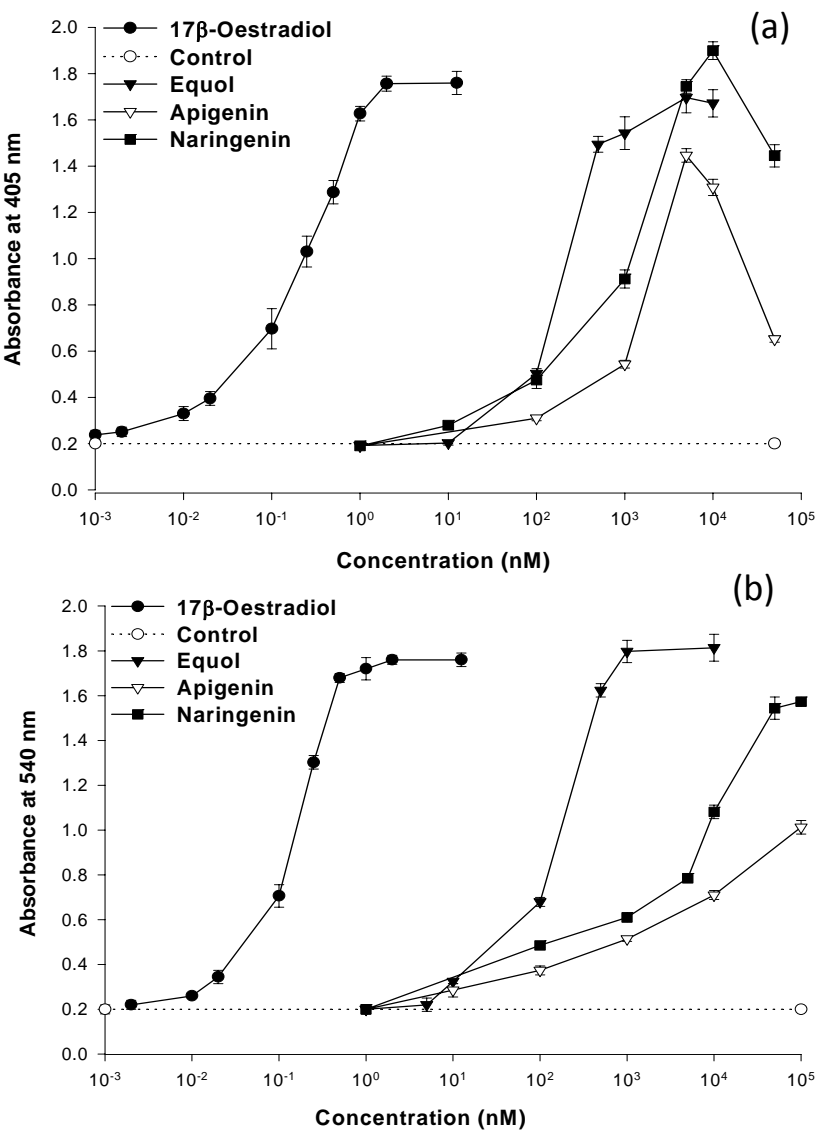

Data are expressed as mean \pm SEM ( $n=10$ wells per point),

Where no error bars are visible, the errors were smaller than
Research article

CIndian Society for Education and Environment (iSee) the symbols.

J.C.Kalita \& S.R.Milligan Indian J.Sci.Technol. 
aglycone forms (Table $1 \&$ 2). Kaempferol exhibited very weak estrogenic activity in both the assays. Other chemicals like luteolin, quercetin, rutin, catechin and hesperetin did not show any estrogenic activity, even when they were tested at higher concentrations.

Fig. 3. Dose response stimulation of alkaline phosphatase activity in Ishikawa cells (a) \& $\beta$ galactosidase activity in yeast cells (b) by $17 \beta$ estradiol \& phloridzin, quercetin, kaempferol, rutin, Iuteolin, catechin \& resveratrol.
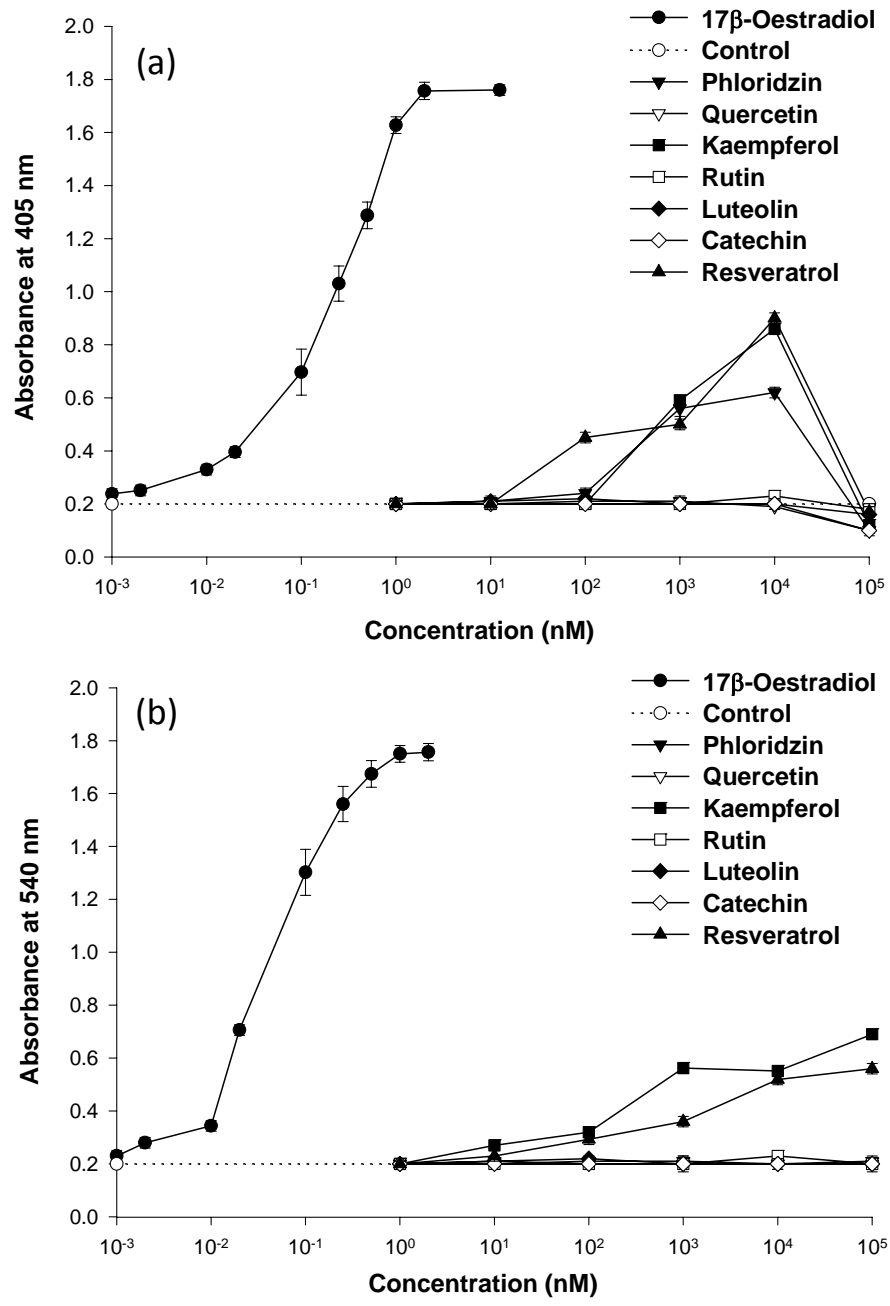

Data are expressed as mean \pm SEM ( $n=10$ wells per point), Where no error bars are visible, the errors were smaller than the symbols.

\section{Discussion}

The testing of new estrogens coupled with the necessity of determining the potential estrogeniciy of many seemingly unrelated pharmaceuticals, pesticides, food products, plant materials and environmental pollutants have led to the development of a number of new in vitro estrogen bioassays. Studies in the 1970s revealed that $99 \%$ of the isoflavonoids compounds in soy are present as their glucosides. The glucosides are converted by digestive enzymes to exert their biological effects. Genistin is also converted to a more familiar genistein, thus, the biological activities including antiatherosclerotic, estrogenic and anitcancer effects are analogous. When ingested along the diet, genistin is readily converted to its aglycone form genistein. It is hydrolyzed by removing the covalently bound glucose to form genistein which is absorbed in the intestine and also responsible for the biological activities of the isoflavone. The gut microflora played a large role in the conversion of genistin to genistein (Coldham et al., 2001). The widespread distribution of flavonoids, their variety and their relatively low toxicity compared to other active plant compounds (for example alkaloids) mean that many animals, including humans, ingest significant quantities in their diet.

The results of the present study established the weak estrogenic activity of phytoestrogen glycosides, some plant flavonoids and other plant-derived phenolic compounds. The results were in agreement with those of other workers (Mayr et al., 1992; Markiewicz et al., 1993; Zava \& Duwe, 1997) who used the Ishikawa assay and other in vitro assays. In their estimates the relative potency of equol was much lower than coumestrol and genistein. In a study Zava and Duwe (1997) showed the potency of equol was equal to genistein in the induction of pS2 in MCF-7 cells and RBA for ER in the intact MCF-7 cells.

The present results were also consistent with the findings of Miksicek (1994) and McLachlan et al. (1997) who used recombinant yeast estrogen assay to measure the abilities of some phytoestrogens in competing with

Table 1. Concentrations at which the phytoestrogens exert one-half of their maximum effects (EC $C_{50}$ ) on stimulation of alkaline phosphatase activity in Ishikawa cells.

\begin{tabular}{|c|c|c|c|}
\hline Compounds & $\begin{array}{l}\text { No. of } \\
\text { expt. }\end{array}$ & $\begin{array}{c}E_{50}(n M) \\
\text { Mean } \pm \text { SD }\end{array}$ & $\begin{array}{c}\text { Relative } \\
\text { potencies }\end{array}$ \\
\hline $17 \beta$-estradiol & 5 & $0.33 \pm 0.11$ & 100 \\
\hline \multicolumn{4}{|l|}{ Isoflavones } \\
\hline Genistein & 5 & $289 \pm 26$ & 0.11 \\
\hline Genistin & 5 & $557 \pm 157$ & 0.06 \\
\hline Daidzein & 5 & $437 \pm 145$ & 0.08 \\
\hline Daidzin & 5 & $446 \pm 60$ & 0.07 \\
\hline \multicolumn{4}{|l|}{ Isoflavan } \\
\hline (+/-) Equol & 5 & $183 \pm 28$ & 0.18 \\
\hline \multicolumn{4}{|l|}{ Flavone } \\
\hline Apigenin & 5 & $2261 \pm 173$ & 0.02 \\
\hline Luteolin & 5 & no effect & - \\
\hline \multicolumn{4}{|l|}{ Flavonol } \\
\hline Kaempferol & 5 & $>10000$ & $<0.003$ \\
\hline Quercetin & 5 & no effect & - \\
\hline Rutin & 5 & no effect & - \\
\hline \multicolumn{4}{|l|}{ Flavanol } \\
\hline$(+/-)$ Catechin & 3 & no effect & - \\
\hline \multicolumn{4}{|l|}{ Flavanone } \\
\hline Hesperetin & 3 & no effect & - \\
\hline Resveratrol & 3 & $>10000$ & $<0.003$ \\
\hline Naringenin & 3 & $869 \pm 95$ & 0.04 \\
\hline
\end{tabular}


${ }^{[3 H]} 17 \beta$-estradiol for binding to the recombinant hER. In their studies the $E C_{50}$ values for coumestrol, genistein, biochanin $\mathrm{A}$, chrysin and naringenin were determined as $0.01 \mathrm{M}, 2.0 \mathrm{M}, 6.0 \mathrm{M}, 33 \mathrm{M}$ and $45 \mathrm{M}$. The potential estrogenic activity of plant-derived chemicals such as kaempferol and quercetin are contradictory. In the present study, several chemicals like luteolin, quercetin, rutin, catechin and hesperetin did not show any estrogenic activity even when they were tested at higher concentrations $\left(10^{-4}-10^{-6} \mathrm{M}\right)$. At higher concentration (100 M) flavonoids may exhibit toxic effects. Mayr et al. (1992) found that at higher concentrations (between $2.5 \times 10^{-5}$ \& $10^{-4} \mathrm{M}$ ), phytoestrogens like genistein, biochanin $A$ and formononetin exhibited toxic effects that resulted in a decreased in protein contents of their MCF-7 cells.

In the present study kaempferol and resveratrol have shown very weak estrogenic activity in both the assays. Based on the concentration of the test compound required to reduce binding of $0.2 \mathrm{nM}^{125} \mathrm{I}$-[17 $\beta$-estradiol] to ER in nuclei of intact MCF-7 cells, Zava \& Duwe (1997) found that quercetin and kaempferol showed very weak affinity for ER. Earlier studies reported that hesperidin, quercetin and rutin could stimulate uterine tissues (Farnsworth et al., 1975a; 1975b). Miksicek (1993) showed that flavonoids like kaempferol, naringenin and apigenin are estrogenic. Zava and Duwe (1997) found that like $E_{2}$ zearalenol, zearalenone, genistein, equol and kaempferol significantly increased the induction of pS2 in MCF-7 cells but not quercetin. In addition to the aglycone forms of the phytoestrogens the present study also established that the genistin and daidzin (the glycosides of genistein \& daidzein respectively), showed up their estrogenic activity in both the bioassays. However, they were found to be less potent than their aglycone forms (Table $1 \&$ 2). In earlier studies using the estrogen sensitive MCF-7 cells (Mayr et al., 1992) showed that daidzin and genistin were found to be about $50 \%$ less active than their aglycone forms. In the uterotrophic assay also daidzin and genistin when given orally to the mice, both the glycosides were found to be less active than their corresponding aglycones (Farmakalidis et al., 1985). The present study firmly confirmed the in vitro estrogenic potency of phytoestrogen glycosides; genistin and daidzin and some other plant chemicals. From the present studies it has been established that both the Ishikawa and the yeast cell assays seem to offer convenient, sensitive methods for determining the estrogenic activities of many plant-derived compounds.

\section{Acknowledgement}

Authors are grateful to the Royal Society, London and Indian National Science Academy (INSA), India for offering Dr. Kalita a Fellowship to work at King's College London, University of London. We are also grateful to Dr. E. Gurpide, Mount Siani School of Medicine, New York and Prof. J. Sumpter, Brunel University, UK for their generous help.
Vol. 3 No. 12 (Dec 2010)

ISSN: 0974- 6846

Table 2. Concentrations at which the phytoestrogens exert one-half of their maximum effects $\left(E C_{50}\right)$ on stimulation of $\beta$-galactosidase activity in recombinant yeast cells.

\begin{tabular}{|c|c|c|c|}
\hline Compounds & $\begin{array}{l}\text { No. of } \\
\text { Expt. }\end{array}$ & $\begin{array}{c}\mathrm{EC}_{50}(\mathrm{nM}) \\
\text { Mean } \pm \mathrm{SD}\end{array}$ & $\begin{array}{c}\text { Relative } \\
\text { potencies }\end{array}$ \\
\hline $17 \beta$-estradiol & 5 & $0.22 \pm 0.06$ & 100 \\
\hline \multicolumn{4}{|c|}{ Isoflavones } \\
\hline Genistein & 5 & $214 \pm 37$ & 0.10 \\
\hline Genistin & 5 & $2373 \pm 649$ & 0.01 \\
\hline Daidzein & 5 & $1415 \pm 113$ & 0.02 \\
\hline Daidzin & 5 & $\sim 10000 \pm 460$ & 0.002 \\
\hline \multicolumn{4}{|c|}{ Isoflavan } \\
\hline (+/-) Equol & 5 & $138 \pm 38$ & 0.16 \\
\hline \multicolumn{4}{|l|}{ Flavone } \\
\hline Apigenin & 5 & $>10000$ & - \\
\hline Luteolin & 5 & no effect & - \\
\hline \multicolumn{4}{|c|}{ Flavonol } \\
\hline Kaempferol & 5 & $>10000$ & $<0.002$ \\
\hline Quercetin & 5 & no effect & - \\
\hline Rutin & 5 & no effect & - \\
\hline \multicolumn{4}{|c|}{ Flavanol } \\
\hline$(+/-)$ Catechin & 3 & no effect & - \\
\hline \multicolumn{4}{|l|}{ Flavanone } \\
\hline Hesperetin & 3 & no effect & - \\
\hline Resveratrol & & $>10000$ & $<0.002$ \\
\hline Naringenin & 3 & $1970 \pm 1533$ & 0.003 \\
\hline
\end{tabular}

Relative potencies were expressed as:

$\left[E C_{50}\left(E_{2}\right) / E C_{50}\right.$ (compound) $\times 100$.

\section{References}

1. Anderson JJ, Anthony MS, Jordan VC and Vergotel (1999): Health potentials of soy isoflavones for menopausal women. Public Health Nutr. 2, 489-504.

2. Arvidson NG (1977) Early oestrogen-induced changes in uterine albumin exchange in mice. Acta Physiol. Scand. 100, 325-331.

3. Barrett J (1996) Phytoestrogens: Friends or foes? Environ. Health Perspectives. 104, 478-482.

4. Benson GK, Cowie AT and Hosking ZD (1961) Mammogenic activity of miroestrol. J. Endocrinol. 21, 401-409.

5. Bickoff EM, Livingston AL, Hendrickson AP and Booth (1962) Relative potencies of several estrogen-like compounds found in forages. J. Agric. Food. Chem. 10, 410-412.

6. Bitter GA (2007) Regulation of human estrogen receptor alpha-mediated gene transactivation in Saccharomyces cerevisiae by human co-activator and corepressor proteins. J. Steroid Biochem. Mol. Biol. 103, 189-195.

7. Boonchird $\mathrm{C}$, Mahapanichkul $\mathrm{T}$ and Cherdshewasart W (2010) Differential binding with ERa and ER $\beta$ of the phytoestrogen-rich plant Pueraria mirifica. Braz. J. Med. Biol. Res. 43(2), 195-200.

8. Cheng EW, Yoder L, Story CD and Burroughs W (1954) Estrogenic activity of some isoflavanoid derivatives. Science.120, 575-576.

9. Cherdshewasart W, Sriwatcharakul S and Malaivijitnond S (2008) Variance of estrogenic activity
Research article

CIndian Society for Education and Environment (iSee)
"Phytoestrogen" http://www.indjst.org
J.C.Kalita \& S.R.Milligan Indian J.Sci.Technol. 
of the phytoestrogen-rich plant. Maturitas. 61, 350357.

10.Colborn T, Dumanski D and Myers JP (1996) Our stolen future. New York: Penguin Books, Inc.

11.Coldham NG, Darby C, Hows M, King LJ, Zhang AQ and Sauer MJ (2001) Comparative metabolism of genistin by human and rat gut microflora: Detection and identification of the end-products of metabolism. Xenobiotica. 22(10), 45-62.

12.Cushnie TPT and Lamb AJ (2005) Antimicrobial activity of flavonoids. Int. J. Antimicrob. Agents. 26(5), 343-356.

13.Davis SR, Dalais FS, Simpson ER and Murkies AL (1999) Phytoestrogens in health and disease. Recent Prog. Horm. Res. 54,185-210.

14.De Sousa RR, Queiroz KC, Souza AC, Gurgueira SA, Augusto AC, Miranda MA, Peppelenbosch MP, Ferreira CV and Aoyama H (2007) Phosphoprotein levels, MAPK activities and NFkappaB expression are affected by fisetin. J. Enzyme Inhib. Med. Chem. 22(4), 439-444.

15. Farmakalidis E, Hatchcock IN and Murphy PA (1985) Oestrogenic potency of genistin and daidzin in mice. Food Chem. Toxicol. 23, 741-744.

16. Farnsworth NR, Bingel AS, Cordell GA, Crane FA and Fong HS (1975a) Potential value of plants as sources of new antifertility agents I. J. Pharm. Sci. 64, 535598.

17.Farnsworth NR, Bingel AS, Cordell GA, Crane FA and Fong HS (1975b) Potential value of plants as sources of new antifertility agents II. J. Pharm. Sci. 64, 717753.

18. Galeotti $F$, Barile E, Curir $P$, Dolci, $M$ and Lanzotti V (2008) Flavonoids from carnation (Dianthus caryophyllus) and their antifungal activity. Phytochem. Letts. 1, 44.

19. Harmsen S, Meijerman I, Beijnen JH and Schellens $\mathrm{JH}$ (2007) The role of nuclear receptors in harmacokinetic drug-drug interactions in oncology. Cancer Treat Rev. 33, 369-380.

20.Kalita JC (1998) Studies of plant oestrogens with special reference to hops (Humulus lupulus L.) Ph. D Thesis, King's College, University of London.

21.Kalita JC, Sharma DK and Milligan SR (2006) Oestrogenic potency of certain established dietary phytoestrogens in cell culture bioassay. $A d v$. Reproductive Toxicol. Pointer publishers, Jaipur, India. Eds. pp: 273-293.

22.Keung WM and Vallee BL (1998) Kudzu root: An ancient Chinese source of modern antidipsotropic agents. Phytochem. 47(4), 499-506.

23. Littlefield BA, Gurpide E, Markiewicz L, McKinley B and Hochberg RB (1990) A Simple and sensitive microtiter plate estrogen bioassay based on Stimulation of alkaline phosphatase in Ishikawa cells: Estrogen action of adrenal steroids. Endocrinol. 127, 2757-2761.
24.Malaivijitnond S, Chansri K, Kijkuokul P, Urasopon N and Cherd-shewasart W (2006) Using vaginal cytology to assess the estro-genic activity of phytoestrogen-rich herb. J. Ethnopharmacol. 107, 354-360.

25. Markiewicz L, Garey J, Adlercreutz H and Gurpide E (1993) In vitro bioassays of non-steroidal phytoestrogens. J. Steroid Biochem. Mol. Biol. 45, 399-405.

26. Mayr U, Butsch A and Schneider S (1992) Validation of two in vitro test systems for estrogenic activities with zearalenone, phytoestrogens and cereal extracts. Toxicol. 74, 135-149.

27. McLachlan et al. (1997) Synergistic effects of environmental estrogens: Report withdrawn. Science. 277,459

28. Miksicek RJ (1993) Commonly occurring plant flavonoids have estrogenic activity. Mol. Pharmacol. 44, 37-43.

29. Miksicek RJ (1994) Interaction of naturally occurring nonsteroidal estrogens with expressed recombinant human estrogen receptor. J. Steroid Biochem. Molec. Biol. 49, 153-160.

30.Milligan SR, Balasubramanian AV and Kalita JC (1998) Relative potency of xenobiotic estrogens in an acute in vivo mammalian assay. Environ. Health Perspec. 106, 23-26.

31.Osman S and Fett W (1983) Isoflavone glucoside stress metabolites of soybean leaves. Phytochem. 22, 1921.

32.Ramsey LA, Ross BS and Fischer RG (1999) Phytoestrogens and the management of menopause. Adv. Nurse Practitioners. 7, 26-30.

33. Rezvani A (2003) Plant derivatives in the treatment of alcohol dependency. Pharmacol. Biochem. Behavior. 75, 593.

34.Routledge EJ and Sumpter JP (1996) Estrogenic activity of surfactants and some of their degradation products assessed using a recombinant yeast screen. Environ. Toxicol. Chem. 15, 241-248.

35.Russell L, Swink Hicks G, Low AK, Sheperd JM and Brown CA (2002) Phytoestrogens: A viable option? Am. J. Med. Sci. 324(4), 185-188.

36. Spencer and Jeremy PE (2008) Flavonoids: Modulators of brain function? British J. Nutrition. 99, 60-77.

37.Whitten PL, Russell E and Naftolin F (1992) Effects of a normal, human-concentration, phytoestrogen diet on rat uterine growth. Steroids. 57, 99-106.

38. Yamamoto $Y$ and Richard B Gaynor (2001) Therapeutic potential of inhibition of the NF-kB pathway in the treatment of inflammation and cancer. J. Clin. Invest. 107(2), 135-142.

39. Zava DT and Duwe G (1997) Estrogenic and antiproliferative properties of genistein and other flavonoids in human breast cancer cells in vitro. Nutr. Cancer. 27, 31-40.
J.C.Kalita \& S.R.Milligan Indian J.Sci.Technol. 